\title{
Ekonomi Kapitalisme
}

Alyaghina Ismirana/90100118115

Kapitalisme adalah suatu system ekonomi (social) yang bercirikan frofit motive dan control terhadap sarana produksi, distribusi, dan pertukaran oleh kepemilikan pribadi. Definisi ini bisa menjadi titik berangkat bagi kita. System social dan ekonomi yang ada saat ini dicirikan dengan profit motive. Kapitalisme juga adalah sebuah system yang berbasis pada control terhadap sarana produksi, distribusi, dan pertukaran barang oleh private ownership. Dominasi prinsip keuntungan dan private property sebenarnya saling terkait.

Bagi Karl Marx, esensi dari sistem kapitalisme adalah pelipat gandaan kapital (uang). Dengan uang para kapitalis membeli tenaga kerja dan mesin produksi untuk menghasilkan komoditas. Setelah komoditas dihasilkan para kapitalis menjualnya lagi untuk mendapatkan uang yang lebih banyak lagi. Sirkulasi pertukaran barang dan perubahan uang menjadi komoditas dan berubah lagi menjadi uang, di kenal dengan pola M -C -M.3 Nilai lebih yang diambil oleh kaum kapitalis dari kaum buruh pada dasarnya adalah sebuah tindakan pencurian terhadap hak-hak kaum buruh yang di sebut Karl Marx sebagai tindakan eksploitasi. Modal atau kapital dapat diibaratkan seperti uang yang dipergunakan untuk memperoleh lebih banyak uang. Modal adalah uang yang tidak digunakan untuk membeli barang-barang kebutuhan ataupun barang-barang yang diinginkan individu. Modal adalah uang yang ditanam supaya tumbuh dan menghasilkan lebih banyak uang.

\section{Bentuk sederhana; the money circuit of capital}

Selanjutnya penjelasan mengenai makna dan implikasi dari masyarakat yang berbasis pada profit motive dan profit proverty atas sarana produksi. Dimana symbol M untuk uang yang dilemparkan ke dalam proses akumulasi dengan tujuan mencari untung, dan $\mathrm{C}$ sebagai nilai komoditas yang dibeli dengan uang tadi dan dijual kembali untuk mendapatkan uang yang lebih banyak M'

$$
\mathrm{M}-\mathrm{C}-\mathrm{M}^{\prime}
$$


Uang harus menjadi komoditas $\mathrm{C}$ dan komoditas harus menjadi uang lagi dengan cara dijual kembali. Inilah yang disebut dnegan the money circuit of capital. Uang di dapat dari mennjual komoditi tadi haruslah lebih besar. Sebenarnya, $M^{\prime}=M+\Delta M$, di mana $\Delta M$ jumlah uang yang didapat.

Lingkaran M - C - M'tidak berhenti di situ saja. Sang kapitalis, setelah mendapat M', motif mencari untungnya membuat ia membeli lagi komoditas C' dalam rangka mendapatkan uang lebih banyak M", begitu seterusnya.

Jadi aktifitas mencari keuntungan secara inheren tidak terbatas. Ini adalah titik krusial yang harus kita pahami secara utuh, karena implikasinya yang sangat luas. Pada gambar di atas kita bisa menambahkan $\mathrm{M}$ dan $\mathrm{C}$ secara terus menerus, karena tidak ada batasan dalam mencari keuntungan. Diakatakan ínheren' untuk menekankan bahwa logika mencari keuntungan tidak mengenal batas apapun.

Selanjutnya pengembangan dari money circuit of capital untuk melihat hubungan profit dan produksi. Produksi untuk profit mengandaikan adanya dua hal penting. Pertama, sarana produksi, distribusi dan pertukaran harus terkonsentrasi pada satu tangan. Kedua, adalah pasar tenaga kerja, sebuah pasar di mana orang-orang mencari kerja untuk mendapatkan upah. Tanpa dua hal ini, profit motive tidak bisa menghasilkan keuntungan yang sebenarnya. Berikut formulanya:

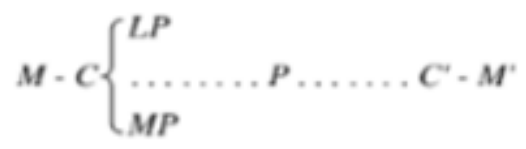

C dibagi menjadi dua bagian, yaitu LP adalah labour power, sedangkan MP adalah means of production. labour power adalah kapasitas untuk bekerja yang dijual oleh pekerja kepada sang kapitalis. means of production adalah semua instrumen yang digunakan oleh LP ketika aktifitas bekerja terjadi untuk menciptakan produk baru. Ketika LP dan MP disatukan, maka terjadilah proses produksi. Proses iini disimbolkan dengan .............., karena disini kita membicarakan mengenai energy hidup yang masuk ke proses kerja. C' adalah komoditi baru 
yang dihasilkan juga dengan nilai baru. Kemudian dijual dan menghasilkan $\Delta \mathrm{M}$ atau $\mathrm{M}$ '. jadi, pengerahan tenaga kerja berada di pusat dari bentuk pengembangan money circuit of capital ini. Jadi karakter akumulasi tanpa batas ini berarti juga kerja tanpa batas.

Munculnya kelas-kelas sosial dan hak milik atas alat-alat produksi disebabkan karena usaha manusia untuk mengamankan dan memperbaiki keadaan hidup. Usaha ini dilakukan dengan pembagian kerja yang semakin spesialis. Masyarakat terbagi menjadi dua, yakni kelas penguasa dan kelas pekerja. Pembagian yang semakin spesialis inilah yang akhirnya membuat perbedaan tajam antara hidup seseorang yang berada di kelas penguasa dan kelas bawah. Oleh karena itu Mark di dalam bukunya "the Communist Manifesto" berusaha mengubah faham kapitalus menjadi komunis menurut Karl Marx. Namun hal itu tidak semudah untuk merubah keadaan yang pada awalnya menganut paham kapitalis menjadi sebuah keadaan tanpa hak atas milik pribadi. 


\section{DAFTAR PUSTAKA}

Rahmawati, E. (2013). Peranan Kaum Borjuis Terhadap Munculnya Revolusi Prancis (Doctoral dissertation, FIS)

Kambali, M. (2020). Pemikiran Karl Marx Tentang Struktur Masyarakat (Dialektika Infrastruktur Dan Suprastruktur). Jurnal Pemikiran Dan Penelitian Ekonomi Islam, 8(2). hlm. 63-80. https://media.neliti.com/media/publications/332489pemikiran-karl-marxtentang-struktur-mas-fb1b694e.pdf.

Qomar, M. N. (2019, November). Kritik Karl Marx Terhadap Konsep Buruh Kapitalis Kajian Komparatif Ekonomi Syariah Atas Buku Das Kapital I. InProceedings of Annual Conference for Muslim Scholars(Vol. 3, No. 1, pp. 1003-1009).

Sirajuddin, dan Tamsir. (2019).Rekonstruksi Konseptual kepemilikan Harta Prespektif Ekonomi Islam (Studi Kritis Kepemilikan Harta Sistem Ekonomi Kapitalisme). Jurnal Laa Maysir, 6(2). hal. 211-225.

Sholahuddin, M. (2007). Kritik Terhadap Sistem Ekonomisosialis Dan Kapitalis.Jurnal Ekonomi Pembangunan: Kajian Masalah Ekonomi dan Pembangunan,2(2), 193-209. 